\title{
Evidens om bibliotekernes brugere
}

\author{
Af Niels Ole Pors
}

\begin{abstract}
Abstrakt
Formålet med denne artikel er at undersøge i hvilken udstrcekning danske og nordiske brugerundersøgelser kan siges at etablere en forholdsvis sikker viden om brugernes adfcerd, aktiviteter og praferencer. Der gennemgås et mindre antal undersøgelser, der har det fcellestrcek, at de har et videnskabeligt ambitionsniveau. Der er udvalgt undersøgelser publiceret efter 2005, og undersøgelserne har meget forskellig metodeanvendelse. På trods af dette peger analyserne på, at der kan afloeses ensartede tendenser vedrørende de forskellige brugersegmenter. Nogle af hovedresultaterne er, at både uddannelsesbibliotekernes og folkebibliotekernes brugere primart er orienterede mod indhold og tekster, både i forhold til aktiviteter og i forhold til proferencer. Indholdet kan vare både papirbåret eller digitalt, men det vurderes som det vaesentligste af brugerne. Det er ligeledes tydeligt, at det fysiske biblioteksrum betyder meget for brugerne, men at det er scerlige grupper, der iscer anvender det. Det er ligeledes tydeligt, at brugerne har taget dele af det digitale univers til sig, og at det influerer kraftigt på informationsadfcerden. Der er $i$ de gennemgåede undersøgelser ikke mange indikationer på, at brugerne anvender bibliotekerne som mødesteder eller $i$ øvrigt udviser interesse for at forbinde sociale teknologier og lignende med deres biblioteksbrug. Et hovedresultat $i$ undersøgelserne synes faktisk at vare, at brugerne er traditionelle i deres aktivitetsmønster og proferencer.
\end{abstract}

Niels Ole Pors er professor ved Det InformationsvidenskabeligeAkademi.nop@iva.dk

\section{Indledning}

Denne artikel søger at give en oversigt over dele af den faktuelle viden, vi har om især folkebibliotekernes brugere og deres holdninger, præferencer, attituder og adfærd. Denne oversigt er nødvendigvis begrænset både i forhold til geografi og tid. Litteraturen om bibliotekernes brugere er mere end overvældende.

Den foreliggende tekst ikke er et systematisk review af den type som anbefales inden for evidensbevægelsen. Et systematisk review skal traditionelt have klare kriterier for, hvilken litteratur, der skal medtages eller udelukkes. Reviewet skal endvidere have en præcis søgestrategi, hvilket betyder, at det klart skal fremgå, hvor der er søgt litteratur. Endvidere skal reviewet indeholde en systematisk kodning og organisering af de inkluderede studier. Det betragtes også som en fordel, hvis det systematiske review indeholder metaanalyser. Der er ligeledes ofte et krav om, at der er udarbejdet en protokol eller et fagfællebedømt design for udformningen af et review. Man vil også ofte se, at inklusion eller eksklusion af studier i reviewet udføres af flere personer, hvis resultater samstemmes. Endelig skal der også tages stilling til, i hvilken udstrækning såkaldt grå litteratur skal søges og vurderes på samme måde, som der skal tages stilling til, hvor internationalt det systematiske review skal være. Ambitionen er at besvare spørgsmålet om, hvilken viden vi har om fællestræk og tendenser vedrørende bibliotekernes brugere (Pettigrew \& Roberts, 2006). 
Teksten er en gennemgang af nogle forholdsvis indflydelsesrige tekster, der repræsenterer opsummeringer af en viden, der haves om brugere og deres holdninger til og ageren i forhold til biblioteker og informationssystemer.

Artiklen behandler ikke undersøgelser uden for det nordiske område, men i artiklens afsluttende del peges der dog på enkelte udenlandske resultater som en art perspektivering på de nordiske. Der lægges vægt på undersøgelser fra 2005 og fremefter. Året 2005 er valgt, fordi der på dette tidspunkt for alvor sker noget vedrørende digitale tjenester. Denne udvikling har været i gang tidligere, men det er i midten af årtiet, at brugen af elektroniske ressourcer for alvor slår igennem, mest i forskningsbibliotekerne, men til en vis grad også i folkebibliotekerne, hvor brugerne $\mathrm{i}$ stigende grad tager netmusik, bibliotek.dk, litteratursiden.dk og anvendelsen af lokale data-baser til sig.

I selve artiklen lægges der vægt på at se på de tendenser, der måtte være i brugernes adfærd, holdninger, præferencer og tilfredshed. Ikke alle undersøgelserne behandler alle emnerne på samme måde, men det er vigtigt at se på, om brugernes adfærd ændrer sig og diskutere mulige grunde til adfærdsændringer, herunder også at se på skift i opfattelserne hos brugerne.

En artikel af denne størrelse kan selvsagt ikke give endelige svar, men den kan forhåbentligt give en klar indikation af, hvor sikker vor viden er om brugere, herunder hvor forskellige distinkte brugergrupper er.

Der er sket en stor udvikling i brugerundersøgelser de seneste årtier. Udviklingen er primært sket indenfor den type undersøgelser, der beskæftiger sig med brugernes tilfredshed og forventninger. Disse undersøgelser er kendetegnet ved at være næsten standardiserede måleinstrumenter, hvilket betyder, at de kan anvendes både til sammenligning mellem organisationer og til sammenligning over tid. Denne type undersøgelser kan næsten alle relateres til servicekvalitetsmodellen, der blev udviklet i slutningen af 1980'erne (Hernon \& Altman, 1996). Det er også tankegangen i denne type undersøgelser, der ligger bag de seneste store brugerundersøgelser, som Biblioteksstyrelsen (nu Styrelsen for Bibliotek og Medier) har været igangsætter for, og som er afprøvet på flere folke- og forskningsbiblioteker. Disse undersøgelser er baseret på Dansk Kundeindeks og Europe- an Customer Satisfaction Index. Målet er at opstille en model, hvorigennem det analyseres, hvor meget brugernes opfattelse af serviceniveauet på forskellige forhold influerer på den opfattede værdi og på tilfredsheden. Gennem denne model beregnes også en loyalitetsscore. Da disse undersøgelser næsten alle ligger før 2005, vil de kun blive inddraget sporadisk, fordi de betjener sig af et standardiseret måleinstrument (Martensen \& Grønholt, 2003).

Det i øjeblikket mest udbredte instrument er LibQual-protokollen, der gennem de sidste 10 år er slået meget stærkt igennem i bibliotekssektoren. Dette instrument har den meget store fortjeneste, at det er testet meget omhyggeligt (Heath, 2004; Kyrillidou, 2009; Thomson et al, 2009)

Situationen er meget anderledes, når vi ser på undersøgelser af brugeradfærd i biblioteker. Her har vi ikke samme type standardiserede undersøgelser. Vi har derimod en række indicier, der viser en ændret brugeradfærd i bibliotekerne. Indicierne stammer fra de årlige biblioteksstatistikker og andre typer af tællinger. Andre bygger på observation af, hvad der sker. Det kan være observationer af, hvorledes brugerne bevæger sig rundt $i$ bibliotekerne og observationer af, hvad de faktisk foretager sig. Det vil man næppe i alle tilfælde kunne fange op gennem $\mathrm{fx}$ spørgeskemaundersøgelser. Der er ikke i tvivl om, at adfærden også i de kommende år skal indfanges gennem anvendelse af en mangfoldighed af forskellige metoder. Det forhindrer ikke at målet også her er at få en mere generel viden.

I biblioteksforskningen er der kun i begrænset omfang arbejdet med generelle modeller om brugeradfærd, men det er der inden for den informationsvidenskabelige forskning. Her har modeller om informationssøgning og informationsadfærd været meget centrale de seneste årtier. Der er ingen tvivl om, at der vil kunne hentes megen inspiration herfra, og en god og interessant sidegevinst kunne faktisk være, at biblioteksundersøgelser bliver placeret i en lidt bredere sammenhæng.

I artiklen lægges særlig vægt på danske undersøgelser, hvor der behandles en blanding af landsdækkende undersøgelser og mere lokale undersøgelser blandt andet for at undersøge om landsdækkende tendenser kan genfindes i det lokale. Som baggrund præsenteres enkelte resultater fra en omfattende kul- 
tur- og fritidsundersøgelse (Bille et al, 2004). Undersøgelsen er foretaget før denne artikels kronologiske afgrænsning, men undersøgelsen er så vigtig, at det er vurderet, at den bør omtales som baggrund. Der startes med en forholdsvis simpel undersøgelse. I 2009 er der foretaget en såkaldt omnibusundersøgelse af Gallup, hvor der er stillet et repræsentativt udsnit af befolkningen 13 spørgsmål vedrørende deres biblioteksbenyttelse. Denne undersøgelse foregiver ikke at have videnskabelige ambitioner, men resultaterne af den er blevet anvendt i den bibliotekspolitiske debat, hvorfor en kritisk analyse er på sin plads.

En landsdækkende undersøgelse fra 2005 (Pors, 2005) behandles. Den vedrører studerende fra forskellige postgymnasiale uddannelser med henblik på afdækning af deres anvendelse af biblioteker, nettjenester samt studieadfærd. Undersøgelsen indeholder endvidere også informationer om de studerendes anvendelse af folkebiblioteker. Denne undersøgelse sammenlignes med en lidt senere undersøgelse foretaget på flere af de store forskningsbiblioteker (Akselbo et al, 2006) Sammenligningen af undersøgelserne er interessant, fordi de to undersøgelser anvender meget forskellige metoder. Det samme gør sig gældende i forhold til undersøgelser af gymnasieelever (Pors, 2007), der også er en landsdækkende undersøgelse, der inddrager gymnasieelevernes anvendelse af folkebiblioteker foruden deres anvendelse af uddannelsesbiblioteker. Dele af denne undersøgelse sammenlignes med en anden undersøgelse baseret på interviews og fremtidsværksteder, der har samme målgruppe, men som faktisk kommer frem til meget forskellige resultater.

Foruden disse undersøgelser inddrages der også enkelte danske lokale undersøgelser. Der inddrages et mindre udvalg af lokale undersøgelser, der har en vis analytisk ambition. Et element i nogle af de lokale undersøgelser vedrører brugernes præferencer i forhold til de tjenester og ydelser, der betyder mest for dem.

I Norge blev der i 2007 foretaget en større undersøgelse af anvendelsen af biblioteker i større byer (ABM skrift 46, 2007). Denne undersøgelse er interessant, fordi den systematisk har anvendt observation som dataindsamlingsmetode. De svenske SOM - undersøgelser (Höglund \& Wahlström, 2006) er ligeledes interessante. Det er generelle undersøgelse af den svenske befolknings anvendelse af folkebibliote- ker. Disse undersøgelser udgør den øvrige nordiske del af undersøgelsesfeltet.

I både Norge og Sverige er der foretaget større undersøgelser af, hvilke faktorer der påvirker folkebibliotekernes udlånsaktiviteter (Løyland \& Ringstad, 2008; 2010). Disse undersøgelser er meget interessante og meget professionelt udførte og enkelte hovedresultater medtages, selvom undersøgelserne emnemæssigt falder lidt uden for rammerne af denne fremstilling.

Samlet giver disse undersøgelser muligheder for at vurdere, i hvilken udstrækning man kan tale om evidens i forbindelse med brugernes holdninger, adfærd og præferencer. Undersøgelserne kan endvidere anvendes til at vurdere nationale forskelle og - i mindre udstrækning - udviklingstræk, der kan være af stor betydning for at vurdere ændringer i adfærd og holdninger. Samlet set giver undersøgelserne også muligheder for at vurdere forskelle mellem forskellige segmenter af brugere og ikke - brugere.

Undersøgelserne gennemgås hver for sig, og der gives et analytisk signalement af dem. Det betyder, at selve fremstillingen er en blanding af præsentation af emner og resultater i undersøgelserne og analyser af disse.

\section{Analyse af danske undersøgelser}

Det vil være forkert her ikke at nævne med den store kultur- og fritidsaktivitetsundersøgelse (Bille et al, 2004). Den ligger ganske vist før den tidsmæssige afgrænsning, og biblioteksbenyttelsen udgør kun en mindre del af den. Der er imidlertid flere gode grunde til at medtage den. For det første er det en undersøgelse med videnskabelige ambitioner, som tilmed indfries. For det andet er det en metodisk meget velfungerende og velfunderet undersøgelse, der også indeholder en del avancerede analyser. For det tredje er der ikke mange nationale undersøgelser på markedet. Endelig er undersøgelsen én af en længere række af kultur- og fritidsundersøgelser, hvilket muliggør sammenligninger over tid.

I 2004 viser undersøgelsen, at $10 \%$ af den voksne befolkning kommer på et folkebibliotek en gang om ugen, og at 19 \% kommer en gang om måneden. Der er altså tale om, at næsten $30 \%$ kommer på det fysiske bibliotek en gang om måneden eller oftere. 
Denne andel er faldet en smule i forhold til tidligere år. I 2004 er der endvidere $22 \%$ af de voksne, der angiver, at de ikke kommer på biblioteket. Det tilsvarende tal i 1998 var $32 \%$, i 1993 var det $37 \%$ og i 1987 var det $36 \%$. Konklusionen er forholdsvis entydig. Der er i 1994 en større andel af befolkningen end tidligere, der kommer på folkebiblioteket; blot kommer de lidt mindre hyppigt end tidligere.

I undersøgelsen vises det ligeledes, at alder, køn, etnisk oprindelse, urbaniseringsgrad, uddannelse, livsstil, beskæftigelse og indkomst er determinanter i forhold til folkebiblioteksbrug. Kvinder kommer oftere på biblioteket end mænd, og der er flere mænd end kvinder, der angiver, at de aldrig bruger bibliotekerne, idet $29 \%$ af mændene angiver dette mod blot $15 \%$ af kvinderne. De 16 til 19 årige er de hyppigste benyttere, idet de kommer på biblioteket en gang om måneden eller oftere for $40 \%$ s vedkommende. Andelen af dette falder til $35 \%$ for de 20 - 29 årige. Besøgshyppigheden falder med stigende alder og vokser med stigende uddannelsesniveau og falder med indkomsten. Urbaniseringsgraden spiller også ind. Det er især folk i byerne, der kommer hyppigere end mennesker bosat i landkommuner. Uddannelsessøgende er den gruppe, der benytter folkebibliotekerne mest.

I 2004 var det tydeligt at se, at bøger var et meget populært medie, idet hele $85 \%$ angav, at de kom på biblioteket for at låne bøger eller tidsskrifter/blade. Denne andel er den samme som i 1998. 24 \% kommer for at låne musik, hvilket er en fordobling siden 1975. $14 \%$ kommer for at læse aviser eller andet på stedet, hvilket er en andel, der gennem flere år har været konstant. Der spørges også om en række andre aktiviteter, men de fylder ikke meget procentvis. Tallene viser dog meget tydeligt, at brugerne kommer i gennemsnit for at foretage sig flere ting under det enkelte biblioteksbesøg. Det gælder i særlig grad de grupper, der benytter biblioteket ofte. Kvinder synes også at benytte biblioteket til flere ting end mænd. For alle aldersgrupperne gælder det, at der er flest, der kommer for at låne bøger. Musiklån er noget, der primært er forbeholdt den unge gruppe af brugere.

Bibliotekerne benyttes til en flerhed af formål. Fritidsaktiviteter er dominerende, mens også underholdning og kulturoplevelser nævnes af mange samt uddannelse og arbejde. Det er især gruppen under 30 år, der angiver, at de benytter bibliotekerne til uddannelsesformål.

Undersøgelsen har også spurgt om, hvorledes bibliotekernes hjemmesider anvendes. I undersøgelsen er det blot $12 \%$, der har svaret, at de bruger folkebibliotekernes hjemmesider. Hele $73 \%$ angiver, at de aldrig gør det. Her spiller alderen en meget stor rolle således, at brug af hjemmesiderne falder med alderen. Af dem, der benytter hjemmesiderne, er den dominerende aktivitet at søge og bestille litteratur.

\section{Gallupundersøgelse 2009}

Denne undersøgelse er en del af en såkaldt omnibusundersøgelse, hvor der på foranledning af Danmarks Biblioteksforening, HK-kommunal og Bibliotekarforbundet er stillet 13 spørgsmål til et repræsentativt udsnit af den danske befolkning vedrørende brug af og holdninger til folkebibliotekerne (Gallup, 2009). I undersøgelsen indgår der 1.019 borgere over 14 år. Undersøgelsen er foretaget som en internetbaseret undersøgelse, og der er, så vidt man kan se, tale om en undersøgelse af biblioteksbrugere og ikke af befolkningen som helhed. Undersøgelsen foreligger ikke publiceret samlet, men på de to nævnte foreningers hjemmeside kan man få fat i nogle få fordelinger og svar på de 13 spørgsmål, der er stillet.

Undersøgelsen er vanskelig at vurdere, fordi flere spørgsmål er uklare og meget brede. Et spørgsmål lyder: "Hvor ofte bruger du i gennemsnit bibliotekernes internettilbud?" Der er tale om et meget uklart spørgsmål, der forsynder sig mod de mest basale principper for formulering af spørgsmål i spørgeskemaer. Når dette er sagt, er resultatet af svarene i øvrigt, at der næsten ikke er nogen forskel på aldersgruppernes svar. Der er næsten heller ingen forskel på angivelse af hyppighed i forhold til køn.

Et tredje spørgsmål - der heller ikke er særlig klart - vedrører, hvorfor man går på biblioteket. Her har brugerne haft mulighed for at angive flere svar. Topscoren blandt svarene er, at man kommer for at låne bøger. Det svarer $80 \%$ af mændene og $92 \%$ af kvinderne bekræftende på. Det samme spørgsmål besvares med samme høje procenter, når vi ser på andre aldersgrupper. 91 \% af de 15-29-årige svarer således bekræftende og denne procentdel falder til $89 \%$ for de 30-39-årige, og ligger omkring 84-85\% for de aldersgrupper, der er ældre. 
Omkring en tredjedel angiver, at de kommer for at låne elektroniske medier. Dette er angivet som musik, lydbøger, videoer og spil. Mænd og kvinder gør det i stort set samme omfang. Det er ikke overraskende, at den yngste aldersgruppe på 15-29 år svarede bekræftende for $41 \% \mathrm{~s}$ vedkommende. Denne andel falder jæunt til $38 \%$ for de 30-39-årige. Den er $34 \%$ for personer i fyrrerne, $32 \%$ for personer i halvtredserne, mens $25 \%$ af personer over 60 år angiver dette som en af grundene til biblioteksbesøg. Der er altså ikke uventet forskelle i forhold til alderen, men det er måske mere overraskende, at forskellene trods alt er så små, som de er.

Respondenterne er også blevet bedt om at angive, hvor lang tid de i gennemsnit anvender på et biblioteksbesøg. $67 \%$ af mændene angiver, at de anvender mindre end en halv time, mens den tilsvarende andel for kvinder er $68 \%$. Der er mindre aldersmæssige svingninger, hvor vi kan se at den yngste aldersgruppe bruger mindst tid og brugere i 30'erne, som i større udstrækning end andre grupper kommer med børn, anvender længst tid.. Forskellene er dog små og resultaterne harmonerer med andre undersøgelser.

Vi kan også se, at anvendelse af selvbetjening ved lån og aflevering er meget udbredt, idet omkring trefjerdedele af respondenterne angiver, at de gør dette de fleste gange. Kvinder gør det i lidt større udstrækning end mænd. Andelen, der anvender selvbetjening, falder med alderen fra $81 \%$ for de 15-29-årige til $67 \%$ for aldersgruppen over 60 år.

Det er også interessant at konstatere, at det er den yngste aldersgruppe, der i størst udstrækning søger vejledning hos personalet.

Cirka en fjerdedel af respondenterne angiver - næsten uafhængigt af køn og alder - at de regner med, at de vil anvende digitale tilbud fra bibliotekerne $\mathrm{i}$ større omfang end nu om to år.

Der er stillet et interessant spørgsmål, som måske er det vigtigste i undersøgelsen, og som vedrører, hvad der kunne få respondenterne til at bruge biblioteket mere i fremtiden. Spørgsmålet lyder: "Hvilke ændringer kunne få dig til at bruge biblioteket mere om to år end i dag?" Indirekte er der tale om undersøgelse af præferencer og ønsker. Der er tre klare topscorere i forhold til dette spørgsmål. Det er først og fremmest et udvidet udbud af bøger. $25 \%$ af mæn- dene og $30 \%$ af kvinderne angiver dette som et forhold, der kunne øge deres biblioteksbenyttelse. $34 \%$ af den yngste aldersgruppe angiver også dette. Nummer to på listen er et udvidet udbud af elektroniske medier, hvor $23 \%$ af mændene og $19 \%$ af kvinderne angiver, at et sådant kunne få dem til at gå oftere på biblioteket. $27 \%$ af respondenterne under 40 svarer bekræftende på dette, hvorefter andelen falder for de ældre grupper. Det tredje ønske er længere åbningstid, herunder åbning i weekender, hvor vi kan se, at det især er gruppen i 30'erne, der mener, at dette kunne få dem til at øge deres besøgsfrekvens. Der er også ønske om cafeteria på bibliotekerne.

Alt $\mathrm{i}$ alt aftegner præferencestrukturen et forholdsvist traditionelt billede, idet materialerne betyder meget for respondenternes oplevelse af, hvad der kunne få dem til at anvende biblioteket mere.

I forhold til denne undersøgelse er det mest interessante i virkeligheden professionens markedsføring af resultaterne, hvor der især er lagt vægt på, at et udvidet tilbud af elektroniske medier vil kunne øge besøgsfrekvensen. Derimod er et udvidet udbud af bøger, som dog er det de fleste respondenter foretrækker, forbigået i høflig tavshed (Pressemeddelelse, 2009).

\section{Studerende og gymnasieelever}

Der er i 2005 gennemført en landsdækkende undersøgelse (Pors 2005) af studerendes biblioteksbenyttelse og deres brug af informationsressourcer. I 2007 blev en tilsvarende undersøgelse (Pors 2007) foretaget vedrørende gymnasieelevers brug af biblioteker og informationsressourcer, herunder deres anvendelse af folkebiblioteker.

Begge undersøgelser var spørgeskemabaserede undersøgelser, der var foretaget online. I begge undersøgelser har man et stort antal svar, henholdsvis næsten 1.700 og 1.000, men der er ikke sikkerhed for, at undersøgelserne er repræsentative i statistisk forstand på trods af undersøgelsernes ambition om dette.

I begge undersøgelser blev der spurgt om brugen af uddannelsesbiblioteket og brugen af andre biblioteker, herunder folkebiblioteker. Undersøgelserne søgte ligeledes at afdække brugen af søgemaskiner og forskellige typer af web-baserede informationstje- 
nester, hvor der især blev fokuseret på en række af de tjenester, der er startet af biblioteker.

Undersøgelsen af de studerende på de videregående uddannelser viste meget tydeligt, at Google ikke i sig selv var en konkurrent til bibliotekerne, hvilket ellers var en dominerende opfattelse på det tidspunkt, som undersøgelsen blev foretaget på. Undersøgelsen viste tværtimod, at de studerende, der i stor udstrækning anvendte Google, delte sig i to grupper, hvoraf den ene også havde en meget intensiv biblioteksbenyttelse. Den anden gruppe med en høj benyttelsesfrekvens af Google havde en meget lille brug af biblioteker. For mange studerendes vedkommende supplerer Google og biblioteksressourcer altså hinanden. Det viser sig fx også ved, at studerende, der anvender Google meget, også låner mange bøger på forskningsbibliotekerne.

Undersøgelsen om studerendes brug af biblioteker og informationsressourcer peger på flere forhold af interesse for biblioteksfolk.

Først og fremmest er det vigtigt at understrege, at det traditionelle mønster for biblioteksbrug ikke er særlig meget på retur. Studerende kommer stadig på biblioteket i ganske stor udstrækning på samme måde, som de har taget de elektroniske ressourcer til sig. Disse anvendes i forholdsvis stor udstrækning både hjemmefra og fra uddannelsesinstitutionen. Studerende låner, fornyer og downloader information $\mathrm{i}$ et ganske stort omfang. Studerende bruger for manges vedkommende flere biblioteker. $85 \%$ bruger et uddannelsesbibliotek. $60 \%$ bruger desuden et folkebibliotek, og næsten halvdelen anvender en flerhed af biblioteker. Det gælder især for studerende fra storbyerne, hvor udbuddet af biblioteker er stort.

Undersøgelsen viser også nogle markante forskelle i benyttelse af information afhængig af studieemne, studietrin og uddannelsestype.

Det er vigtigt at understrege, at der ikke er meget i undersøgelsen, der tyder på, at studerende fravælger fysiske biblioteker. Anvendelsen af digitale ressourcer kommer blot oveni.

Det forhold, der formentlig er det mest afgørende for omfanget af studerendes benyttelse af biblioteker og informationer, er - ikke overraskende - de krav der stilles i studiet. Studerende, hvis lærere omtaler biblioteker som en vigtig ressource og som stiller krav om selvstændig fremfinding og behandling af litteratur, benytter - alt andet lige - biblioteker og formaliserede ressourcer væsentligt mere. Denne meget klare sammenhæng modificeres af fagområder, studietrin og tilsvarende faktorer, hvoraf psykologiske tilbøjeligheder formentlig er en vigtig, men ikke særlig studeret faktor. Den vil ellers være meget væsentlig at forholde sig til i forbindelse med bibliotekernes undervisningsopgaver.

Studerende anvender folkebibliotekerne supplerende og kompenserende. Folkebibliotekerne anvendes meget ofte, når uddannelsesbiblioteket ikke har materialet og som afhentningssted for bibliotek.dk. bestillinger. Der er i materialet indikationer på, at folkebibliotekernes materialevalg indenfor faglitteraturen vurderes meget forskelligt af studerende fra forskellige studieemner.

Generelt peger undersøgelsen på problemer vedrørende markedsføring af formaliserede biblioteksressourcer. Undersøgelsen indikerer endvidere, at uddannelsesbibliotekerne skal ind i et tættere samarbejde med undervisningen på uddannelsesinstitutionerne. Generelle orienterings- og introduktionskurser har formentlig en yderst begrænset effekt. Når man ser på de forskellige gruppers informationsadfærd, kan man med rimelighed spørge, om mange biblioteker ubevidst har etableret forskellige serviceniveauer over for forskellige grupper af studerende- uden at være klar over det.

En helt anderledes undersøgelse af universitetsstuderende præsenteres i undersøgelsen "Det hybride bibliotek set med brugernes øjne" (Akselbo et al., 2006). Denne undersøgelse er interessant af mange grunde. For det første betjener den sig af helt anderledes metoder. Det er interviews, anvendelse af "cultural probes" og andre former for observation. Nogle af de "cultural probes" består i en form for opgaver nærmest i dagbogsform, hvor udsagn, svar på spørgsmål produceres af respondenterne. Andre består af opgaver med et kamera.

Undersøgelsen har i alt inkluderet 32 brugere fordelt på fire større forskningsbiblioteker. Herudover indgår bibliotekarer og et mindre antal forskere i undersøgelsen. Der er altså tale om en udpræget kvalitativ undersøgelse. Undersøgelsen har betjent sig af brugermodellering, og den opererer med tre forskellige 
brugertyper, der er benævnt modelbrugere. Etableringen af modelbrugere er baseret på ideerne om persona. Der er opstillet tre modelbrugere:

\section{Drive-in brugeren, der er karakteriseret ved at} være meget selvhjulpen og som kommer på biblioteket og meget hurtigt ordner sine biblioteksforretninger. Kodeordet er, at man anvender biblioteket som afhentningssted for de materialer, som man har bestilt andet steds fra.

2. Biblioteksentusiasten, der er karakteriseret ved interesse for og til en vis grad en stor viden om bibliotekernes tilbud, der anvendes bredt. Det er ligeledes denne modelgruppe, der har personlige kontakter til personalet

3. Arbejdsbien, der er karakteriseret ved en meget udstrakt anvendelse af bibliotekernes fysiske rammer. Denne modelbruger anvender biblioteket som arbejdsplads uden, at der i øvrigt kan konstateres den store interaktion med bibliotekernes materialer eller personale.

Det fremgår ikke helt klart af undersøgelsen, om der er tale om modelbrugere eller modelbrug. Dette er en svaghed ved undersøgelsen, idet man ikke kan afvise, at den enkelte person i løbet af sin studietid afhængig af arbejdsopgavernes karakter glider ind og ud af de forskellige modelroller, der er opstillet.

Undersøgelsen giver mange interessante oplysninger og informationer om adfærd. Det er tydeligt, at de studerende etablerer et samspil mellem generelle søgemaskiner som Google og bibliotekernes ressourcer og databaser, hvor forholdet er det, at Google i stor udstrækning anvendes i den første eksplorative fase af et projekt, der ligger forud for selve bestillingsfunktionen. Det fremgår også meget tydeligt, at brugerne sætter stor pris på de digitale ydelser som indgang til de fysiske materialer, om end vanskelige søgeflader i nogle tilfælde kan være irritationsmomenter. Personalet opleves som travlt og dermed ikke særligt imødekommende, og personalet er heller ikke synligt på websiderne, hvilket betyder, at man ikke har viden om, hvad de kan bidrage med. Det skal dog understreges, at de brugere, der har fået personlig betjening, har andre og positive oplevelser af personalet. Et markant resultat i undersøgelsen var, at brugerne kun havde meget upræcise og vage forestillinger om personalet og dets kompetencer, herunder spørgsmålet om, hvad man som bruger kan anvende personalet til. Dette forhold kan også skyldes, at de studerendes vurdering af egen kompetence vedrørende biblioteksaktiviteter som udvælgelse af litteratur, litteratursøgning og tilsvarende adskiller sig markant fra bibliotekarernes vurdering af brugernes kompetence. Det skal dog tilføjes, at mange studerende anvender personlige kontakter i deres faglige miljø som hjælp til denne type aktiviteter.

Brugerne anvender primært det fysiske bibliotek som en arbejdsplads, og deres forholden sig til eksperimenter i forhold til det fysiske bibliotek er i bedste fald afventende. Det er tydeligt, at de studerende har en traditionel opfattelse af og adfærd i det fysiske bibliotek.

Undersøgelsen indeholdt også workshops af forskellig art, hvor ønsker og forventninger til bibliotekernes fremtidige tilbud var på dagsordenen.

Også i gymnasieundersøgelsen (Pors, 2007) kunne der opstilles forskellige typer eller grupper af studerende baseret på deres forhold til biblioteker og informationsressourcer. Der var en gruppe, som anvendte både uddannelsesbibliotek og folkebibliotek. Der var grupper, som næsten kun anvendte uddannelsesbiblioteket eller folkebiblioteket, og endelig var der en gruppe, der stort set ikke anvendte biblioteker i forbindelse med deres gymnasieuddannelse.

Generelt er det således, at mange af de observerede forskelle i brug af informationer, informationsressourcer samt biblioteker kan forklares med demografiske og uddannelsesmæssige faktorer som køn, uddannelsesretning, fag, studietrin og opfattelsen af krav for at nævne de vigtigste.

Når vi ser på brugen af nettjenester, er der kun én af de biblioteksskabte nettjenester, der på undersøgelsestidspunkterne for alvor var slået igennem; det var ikke så underligt bibliotek.dk. De fleste af de øvrige nettjenester havde et meget begrænset brug, hvis de studerendes udsagn ellers står til troende. Det skal dog understreges, at gymnasieeleverne i en vis udstrækning anvendte nogle af de studierelaterede nettjenester eller tjenester, der har en direkte anvendelighed i forbindelse med opgaveskrivning som for eksempel SKODA og Infomedia. Gymnasieeleverne pegede i deres kommentarer ligeledes på Wikipedia som en tjeneste, de anvendte meget. 
Vedrørende brugen af det fysiske bibliotek enten som mødested, rum for socialisering, afslapning og hygge eller studieplads viste sig et interessant fælles mønster for de to grupper af studerende.

Både for gymnasieelever og for studerende på de videregående uddannelser var bibliotekerne populære som fysiske steder, men det skal understreges, at populariteten udtrykt gennem anvendelse i begge tilfælde faldt i takt med, at man kom længere frem i uddannelsen. Det indikerer formentligt, at nye studerende har et andet mønster for benyttelse af bibliotekernes fysiske faciliteter end studerende, der er kommet længere frem i uddannelsen. Til gengæld stiger benyttelsen af materialer i både fysisk og digital form jo længere frem, man kommer i studiet.

På baggrund af denne undersøgelse er det vanskeligt at argumentere for, at unge uddannelsessøgende er i færd med at fravælge bibliotekerne. Totredjedele af eleverne anvender biblioteket eller studiecenteret på deres gymnasium. Totredjedele anvender endvidere et folkebibliotek. Halvdelen af eleverne anvender begge typer biblioteker, mens en sjettedel klarer sig helt uden biblioteksbenyttelse. Endvidere fremgår det tydeligt af undersøgelsen, at biblioteksbrug afhænger af gymnasietype, klassetrin, køn og præferencer i forhold til digitale tjenester.

Det billede, der formidles af de unge i rapporten, er forholdsvis traditionelt. De unge ønsker en venlig betjening $\mathrm{i}$ indbydende omgivelser, og de ønsker et righoldigt udvalg af især litteratur og information. De ønsker zoner, hvor der er mulighed for fred og ro og også gerne andre zoner, hvor der er mere café lignende tilstande. Forventningerne og holdningerne er forholdsvis traditionelle.

Undersøgelsen peger på nogle interessante perspektiver i samspillet mellem gymnasieelever og bibliotekerne. For det første peger undersøgelsen på, at det er næsten meningsløst at tale om gruppen af gymnasieelever og dens informationsbehov som helhed. Der er behov for en meget mere detaljeret analyse af de forskelligartede behov og adfærdsmønstre, der afhænger af forhold som gymnasieretning, klassetrin, køn og psykologiske dispositioner, herunder præferencer for forskellige typer af ressourcer og oplevelser af fysiske og digitale informationsrum. Undersøgelsen belyser de mange forskelle blandt gymnasieeleverne, og de har meget stor betydning for, hvorledes de unge studerer, og hvad de bruger som det primære materiale til dette formål. For det andet peger undersøgelsen på, at gymnasieeleverne og informationskompetence er et interessant område at arbejde videre med, idet der er meget klare korrelationer mellem undervisning i dette, informationskompetencens integration i undervisningen, og hvad man kunne kalde den generelle informationsadfærd. For det tredje peger undersøgelsen på, at vurderingen af digitale ressourcer i forhold til de trykte er undergået en forandring. Mange af gymnasieeleverne foretrækker nu det digitale univers, hvilket indikerer at både folkebiblioteker og gymnasiebiblioteker kunne satse endnu mere målrettet mod dette.

Den samlede konklusion er vel, at det kunne være en fordel med en mindre grad af bibliotekarisk konstruktion af de unge, deres adfærd og behov og flere perspektivrige "optikker" på gruppen set som segmenter og deres omfattende brug af information, hvoraf bibliotekernes tilbud er et blandt mange.

\section{Lokale, danske undersøgelser}

I den ovennævnte undersøgelse af gymnasieelever blev der stillet spørgsmål vedrørende betydningen af forskellige ydelser. De samme spørgsmål blev stillet i en lokal brugerundersøgelse, der i 2009 blev foretaget i Lystrup og Tilst (Pors, 2010). Her var der tale om en helt almindelig brugerundersøgelse af brugerne af to forstadsbiblioteker i Århus.

Sammenstillingen af de sæt af præferencer er interessant og fremgår af den følgende tabel.

Det mest interessante i tabel 1er, hvor ensartet gymnasieelever og den almindelige borger prioriterer. De seks mest prioriterede serviceydelser går igen i begge undersøgelser. I begge tilfælde er der tale om, at betydningen af andre serviceydelser vurderes markant lavere. Der er en meget høj grad af lighed i rangordenen for betydningen af serviceydelser. For begge grupper kan man konstatere, at det gode folkebibliotek er et, der ikke er for langt væk, og som har en venlig betjening i tiltrækkende og rolige lokaler, og som er fyldt med faglitteratur og skønlitteratur. Det er altså den traditionelle betjening og de traditionelle ydelser, der er i højsædet, når man spørger brugerne.

Der er dog også nogle forskelle. En af disse er vurderingen af betydningen af bibliotekernes hjemmesider. 


\begin{tabular}{|l|c|c|c|c|}
\hline & gymnasieelever & rang & Lystrup/Tilst & rang \\
\hline Venlig og høflig betjening & 72 & 1 & 90 & 2 \\
\hline Afstand til biblioteket & 67 & 2 & 91 & 1 \\
\hline Lokalerne & 64 & 3 & 84 & 3 \\
\hline Faglitteratur & 62 & 4 & 66 & 5 \\
\hline Stille områder & 59 & 5 & 65 & 6 \\
\hline Skønlitteratur & 55 & 6 & 78 & 4 \\
\hline Afslapningssteder & 43 & 7 & 51 & 8 \\
\hline Musik & 41 & 8 & 46 & 10 \\
\hline Trådløst netværk & 40 & 9 & 21 & 14 \\
\hline Film & 37 & 10 & 47 & 9 \\
\hline Grupperum & 35 & 11 & 15 & 15 \\
\hline PC'ere & 34 & 12 & 28 & 12 \\
\hline Bibliotekets hjemmeside & 34 & 13 & 63 & 7 \\
\hline Studiepladser & 33 & 14 & 21 & 14 \\
\hline Udstillinger, undervisning etc. & 28 & 15 & 45 & 11 \\
\hline N & 978 & & 243 & \\
\hline
\end{tabular}

Tabel 1. Betydningen af tilbud og ydelser. Betydningen er målt på en skala fra 0 - 100 .

Betydningen vurderes meget større i undersøgelsen fra 2009 end den gør i gymnasieundersøgelsen fra 2007. Dette skyldes sandsynligvis, at der i løbet af den mellemliggende periode er blevet mange flere brugere, der anvender de digitale indgange til bibliotekernes serviceydelser.

Endelig skal det understreges, at de bagvedliggende grupperinger af for eksempel elever fra forskellige typer af gymnasier vurderer forskelligt på samme måde, som vi i brugerundersøgelsen fra Tilst og Lystrup også kan se forskelle i prioriteringen baseret på køn, alder og andre demografiske data; der er dog det fælles, at rangordenen i hovedtræk er meget ensartet på tværs af grupperingerne.

Dette står i stor kontrast til det billede, der er formidlet $\mathrm{i}$ en undersøgelse fra Roskilde "Unge og biblioteker" (Kofod \& Sørensen, 2006). Her fremgår det, at de unge ønsker væsentligt mere spræl i bibliotekerne. De ønsker et mediatek, de ønsker fleksible rammer, og de ønsker respekt fra personalets side samt accept af deres adfærd og adfærdsnormer. Frem for alt ønsker de ikke kedsommelighed. Det er et anderledes resultat end denne undersøgelse indikerer. En af grundene er de meget forskellige undersøgelsesdesign. Undersøgelsen fra Roskilde betjente sig af forskellige typer interviews og fremtidsværksteder, hvor de unge skulle illustrere, hvad de gerne så, at folkebiblioteket havde af tilbud i fremtiden. Selve metoden har elementer af afsøgning af muligheder, hvorfor fantasien kommer i spil. Der går muligvis lidt fantasi i processen, og der kommer ikke altid til at foreligge velafbalancerede udsagn, der indikerer, hvad det væsentligste i virkeligheden er. Undersøgelsen peger også på andre aspekter af interaktionen mellem unge og biblioteker, og det drejer sig om, at unge gerne vil respekteres, og at de ikke altid føler sig velkomne på biblioteket.

Det er anderledes med metoden i gymnasieundersøgelsen, der er langt mere traditionel. Det indebærer også, at spørgsmål i større udstrækning er rettet mod det bestående, og undersøgelsesmetoden har derfor en tendens til at pege på konserverende elementer. Undersøgelsen og dens resultater fremtræder derfor langt mindre "sexede" og kan, hvis de ikke tolkes omhyggeligt, give anledning til konserverende beslutninger. Det er en interessant problemstilling for biblioteksledelse, idet man må forvente, at mange tiltag făr en forholdsvis lang indkøringsperiode blandt andet, fordi forventninger til og billedet af bibliotekerne i den grad er bundet i opfattelser af biblioteket, som det så ud for flere år siden. 
En ting er metoderne og deres indflydelse på resultaterne. Noget andet er selve tilgangsvinklen i mange brugerundersøgelser. Her har vi det interessante problem, at undersøgelser af brug og informationsadfærd ofte er institutionsrelaterede, hvorfor designet har vanskeligt ved at indfange mangetydigheden og flerheden i unges informationsadfærd, der jo ikke nødvendigvis følger de grænser og afgrænsninger, vi traditionelt tænker i. Det vil være frugtbart at foretage undersøgelser af informationsadfærden i forhold til hele det informationsunivers, der er relevant for de unge på samme måde, som de mere biblioteksinterne problemstillinger heller ikke bør vurderes uden, at man tager hensyn til mulighederne i både de biblioteksproducerede og de "frie" netressourcer. En høj grad af samspil i servicetilrettelæggelsen vil formentlig være et gode.

Den sidste lokale danske undersøgelse, der skal inddrages, er publiceret i 2010 og vedrører en innovativ undersøgelse foretaget i Hjørring (Suenson, 2010). Undersøgelsen har registreret et mindre antal brugeres bevægelsesmønster i biblioteksrummet ved hjælp af RFID-teknologi, men indeholder også en spørgeskemaundersøgelse. Undersøgelsen er eksplorativ og har som primært formål at undersøge RFID-teknologiens muligheder, fordele og ulemper, i forhold til afdækning af aktivitets- og bevægelsesmønstre i et rum. Hovedresultaterne i de dele af undersøgelsen, der vedrører traditionelle brugeraktiviteter, er ikke omfattende, men det understreges gennem resultaterne, at ugedag har betydning for, hvem der kommer og hvilke aktiviteter, der er dominerende. Især lørdagen skiller sig ud som en dag, hvor familier i større udstrækning end de øvrige dage, kommer samlet. Der er en lille overvægt af kvinder i undersøgelsen, hvilket heller ikke er overraskende. Undersøgelsen indikerer ligeledes, at kvindelige og mandlige brugeres adfærd er forskellig. Kvinderne anvender en større del af rummet og er mere orienteret mod de områder, hvor man kan aflevere materialer og få inspiration til at låne nye. RFID - teknologien giver gode muligheder for at fastlægge opholdstiden i biblioteket. Opholdstiden er beregnet til et gennemsnit på 30 minutter.

Generelt er resultaterne vedrørende brugerne ikke overraskende, men de kan være lidt vanskelige at vurdere. Der indgår et forholdsvis begrænset antal respondenter i undersøgelsen, idet stikprøven er på godt 250. Der er ikke oplysninger i rapporten om udvalgsmetode bortset fra, at det nævnes, at den er tilfældig. Rapporten har heller ikke ræsonnementer over metodiske forhold, nemlig at respondenterne har udfyldt en del af spørgeskemaet, når de gik ind i biblioteket og en anden del, når de gik ud. Det kan teoretisk set have betydet noget for adfærd, bevægelse og aktiviteter. Der er heller ikke en diskussion af, i hvilken udstrækning RFID-teknologien kan have haft adfærdsændrende effekter. Opgørelsen af den gennemsnitlige opholdstid, der er beregnet til cirka 30 minutter, er naturligvis korrekt, men da der er tale om en meget asymmetrisk fordeling havde det været en fordel med en fremstilling baseret på decentiler eller kvartiler. De øvrige resultater adskiller sig ikke markant fra de resultater, der kommer fra andre brugerundersøgelser. Det skal retfærdigvis understreges, at sigtet med projektet primært har været en afprøvning af teknologien til at afdække dens bæredygtighed i forhold til at få indsigt i aktiviteter og be-vægelser i et rum.

\section{Norske og svenske undersøgelser}

I dette afsnit behandles en norsk undersøgelse, der er baseret på trafiktællinger i fem norske storbybiblioteker og en svensk pendant til den danske kultur- og fritidsvane-undersøgelse, der er behandlet tidligere i denne artikel.

Den norske undersøgelse er rettet mod brugen af store byers hovedbiblioteker. Det betyder, at undersøgelsen ikke er repræsentativ for det samlede brug af folkebiblioteker i Norge. Undersøgelsen er en meget fint tilrettelagt undersøgelse, hvor der er taget mange midler i brug for at opnå et dækkende og repræsentativt billede. Undersøgelsen er primært en adfærdsundersøgelse, det vil sige, at vægten er lagt på, hvad biblioteksbesøgende faktisk har foretaget sig af observerbare fænomener under besøget

Der indgår i alt 3.337 observationer af brugere. Der er mellem 500 og 800 observationer på hvert enkelt bibliotek. Det er cirka $5 \%$ af det faktiske antal besøgende, man har observeret. Der er mindre variationer i forhold til de enkelte biblioteker, men der er ikke tvivl om, at undersøgelsen repræsenterer et dækkende billede af adfærden på de fem storbybiblioteker.

Der er en lille overvægt af kvinder blandt de besøgende, og den største brugergruppe er mellem 25 og 45 år. Næsten $80 \%$ af de besøgende har norsk bag- 
grund. Indvandrergrupper synes at være overrepræsenteret blandt de besøgende. Indvandrergrupperne har en højere grad af mænd blandt sig end de norske besøgende.

Over $70 \%$ af de besøgende opholder sig på biblioteket under en halv time. Knap halvdelen af de besøgende låner eller afleverer, og halvdelen af denne gruppe har lån eller aflevering som den eneste aktivitet under besøget. $11 \%$ studerer eller arbejder på biblioteket i mere end en halv time, og lidt flere anvender bibliotekets informationsteknologi. $10 \%$ af de besøgende er avis- og tidsskriftslæsere. Godt en fjerdedel af de besøgende er sammen med andre under biblioteksbesøget, og samme andel henvender sig til personalet.

Den gruppe, der låner, opholder sig i gennemsnit $\mathrm{i}$ meget kortere tid på biblioteket end den gruppe, der ikke låner under besøget.

Der kan registreres kønsmæssige forskelle, idet kvinder låner mere end mænd; de er også i større udstrækning end mænd sammen med andre under besøget. Mænd bruger bibliotekernes informationsteknologi mere end kvinder; de er også de hyppigste avislæsere, og de bruger musiksamlingen mere end kvinder.

Undersøgelsen registrerer også forskelle mellem aldersgrupperne. De unge benytter informationsteknologien mere end de øvrige aldersgrupper; man kan også se, at besøgende i tyverne i større udstrækning end andre studerer på stedet, mens de, der er yngre, i mindre udstrækning låner. Der synes også at være en korrelation mellem anvendelse af aviser og alder, og en negativ korrelation mellem alder og det at være sammen med andre på biblioteket.

I undersøgelsen bliver der konstateret nogle forskelle mellem de fem biblioteker, der indgår i materialet; det rejser spørgsmålet om, i hvilken udstrækning selve indretningen af bibliotekerne og deres profilering af ydelserne, herunder eksistensen af et filialnet, påvirker den faktiske adfærd blandt de besøgende.

Samlet set giver undersøgelsen en meget fin og nuanceret kortlægning af adfærd i storbybiblioteker.

I indledningen til undersøgelsen foretages der sammenligninger til et par danske undersøgelser, der har betjent sig af forskellige typer af trafiktællinger. Det drejer sig om en undersøgelse foretaget af Kommunernes landsforening (KL, 2004) samt en forholdsvis stor undersøgelse foretaget ved Århus Kommunes Biblioteker (Møller, 2005). I undersøgelsen fra Kommunernes Landsforening er der undersøgt besøgsmønstre på over 20 større og mindre biblioteker. Undersøgelsen fra Århus dækker kun hovedbiblioteket i Århus, men viser mange interessante resultater, hvoraf det mest markante og overraskende er, at optællingen registrerer flere mandlige end kvindelige besøgende. Der kan registreres flere lighedspunkter end forskelle mellem de tre undersøgelser, men der er dog også mindre forskelle. De besøgende i Århus låner mere end de norske besøgende, og de århusianske besøgende anvender mindre tid på biblioteket end de norske besøgende. Der synes også at være en svag tendens til, at de norske biblioteker i større udstrækning end det vi ser i Århus-undersøgelsen anvendes som sociale mødesteder.

Den anden danske trafiktælling viser i øvrigt, at der er ganske store forskelle i adfærd afhængig af bibliotekets størrelse. Generelt bekræfter denne undersøgelse de mønstre, der er gennemgået tidligere. Disse observationsstudier har alle den klare fordel, at det gennem resultaterne understreges, at biblioteksbrugere har meget forskellige aktivitetsmønstre, hvilket peger på nødvendigheden af at segmentere.

De svenske SOM-undersøgelser fra 2007 og 2008 er undersøgelser, der indgår i en række af nationale undersøgelser af befolkningens holdning til og anvendelse af folkebibliotekerne. Undersøgelsesrækken kan betragtes som en parallel til de danske kulturog fritidsvaneundersøgelser. I lighed med de danske undersøgelser udgør biblioteksanvendelsen kun en del af den samlede undersøgelse, der altså kortlægger mange mediemæssige og kulturelle forhold. De to undersøgelser behandles samlet, idet hovedvægten dog lægges på undersøgelsen fra 2007; det skal dog understreges, at hovedresultaterne i de to undersøgelser er meget ensartede (Höglund \& Wahlström, 2009; Höglund \& Wahlström, 2009a).

Der er tale om professionelt gennemførte undersøgelser, der baserer sig på en meget omhyggelig stikprøveudtrækning og vurdering, der i vid udstrækning sikrer repræsentativitet og dermed mulighed for at generalisere. Svarprocenten for undersøgelsen i 2007 ligger omkring $60 \%$, således, at der indgår knap 
1.700 respondenter i forhold til biblioteksspørgsmålene. Undersøgelsen indeholder endvidere oplysninger fra den svenske biblioteksstatistik. Disse oplysninger vedrører især udlånsmønstre og besøgstal, bestandsstørrelser og lignende i perioden fra 2000 til 2007 (Nilsson, 2009).

Mange af de tendenser, der fremstilles, genkendes fra de danske undersøgelser. Brugerne er tydeligvis meget orienteret mod lån af både faglitteratur og skønlitteratur, og de har flere formål med deres biblioteksbesøg. Der kan også her konstateres et svagt faldende besøgstal gennem en længere periode; der kan ligeledes registreres et svagt faldende udlån som en trend. Undersøgelsen forklarer dele af disse tendenser med, at befolkningen i en lidt længere periode har øget deres egne bogindkøb, og at mange foretager flere forskellige biblioteksforretninger over internettet, hvilket overflødiggør nogle biblioteksbesøg. Dette fremstår dog mere som antagelser end som en sikker dokumenteret viden. Undersøgelsen forholder sig faktisk ikke til det forhold, der blev fremhævet i den danske parallelle undersøgelse, nemlig at der ikke var færre personer, der anvendte bibliotekerne, men at de blot kom der lidt sjældnere. Endelig er der også det forhold, at mange låner til andre end sig selv. Der findes ingen systematisk viden om i hvilken udstrækning, at dette forhold har ændret gennem de seneste år.

I undersøgelsen indgår der en række spørgsmål om befolkningens holdninger til folkebibliotekerne; det er ikke overraskende, at disse er meget positive. Holdningerne eller attituderne til biblioteket og dets rolle i samfundet udviser en meget stor grad af stabilitet. Den positive holdning er ikke unaturligt korreleret med omfanget af anvendelse. Selv blandt de, som kun bruger biblioteket sjældent eller aldrig, er der en overvejende positiv holdning til bibliotekerne.

Befolkningens attituder og holdninger til biblioteker er yderligere undersøgt gennem formulering af spørgsmål om, i hvilken udstrækning man er villig til at betale mere i skat for at få et bedre bibliotek. Det er altså en lidt simpel udgave af kontingent evalueringsmetodik, der indgår i undersøgelsen. Næsten 80 $\%$ af de adspurgte angiver, at de er villige til at betale mere i skat, hvis det kommer folkebibliotekerne til gode. $23 \%$ er ikke villige til dette. Et tilsvarende spørgsmål blev formuleret i SOM-undersøgelsen fra 1998; her var det $30 \%$, der ikke var villige til at be- tale mere i skat. Det kan altså konstateres, at holdningen til bibliotekerne - målt på skattevilje - er vokset i perioden. Dog er der langt større andele, der er villige til at betale mere i skat, hvis pengene går til skoler, ældreomsorg og kriminalitetsbekæmpelse. Det er en anden måde at sige, at bibliotekerne opfattes som noget meget positivt i samfundet, men at borgerne vurderer, at andre områder trods alt er vigtigere. På samme måde udtaler respondenterne for langt de flestes vedkommende, at de mener, at bibliotekets kerneopgaver skal være gratis.

Undersøgelsen indeholder en række spørgsmål vedrørende tillid til både biblioteker og andre institutioner. Det kan her konstateres, at bibliotekerne er rangeret meget højt på listen over offentlige tilbud og serviceydelser, som borgerne har tillid til.

Samlet set viser undersøgelsen, at folkebibliotekerne har godt tag i befolkningen, og at de værdsættes ganske højt. Undersøgelsen indikerer ligeledes, at det er de traditionelle ydelser der værdsættes højest. Undersøgelsen bekræfter ligeledes det velkendte billede, hvor den mest positive attitude findes blandt dem, der anvender biblioteket meget og blandt dem med høj uddannelse.

I både Norge og Sverige er der gennemført undersøgelser af mere statistisk art vedrørende de faktorer, der påvirker udlånet (Løyland \& Ringstad, 2008; 2010). Der er ikke tale om brugerundersøgelser, men derimod statistisk-økonomisk orienterede analyser af detaljerede data fra biblioteksstatistikker, kulturstatistikker og forskellige kommunalstatistikker, hvor hovedformålet har været at undersøge, betydningen af faktorer på efterspørgslen af folkebibliotekernes ydelser, herunder analyser af, hvilke faktorer der påvirker låneaktiviteterne. Data til den norske undersøgelse (Løyland \& Ringstad, 2008) er fra 2001 til 2004 og falder derfor uden rammerne af denne oversigt, men det bør dog understreges, at et af hovedresultaterne er, at der er en klar positiv sammenhæng mellem omfanget af bogudlån og bestandens størrelse og omfanget af anskaffelser, hvor det er sidste års anskaffelsesomfang, der har den største effekt. Undersøgelsen er blevet gentaget i Sverige, hvor datamaterialet dækker perioden 1995 - 2007. Der er forskelle i resultaterne de to lande imellem, men lighederne er større. Sammenhængen mellem udlån, bestandens størrelse og omfanget af anskaffelser samt åbningstiden er i store træk de samme. En 
interessant forskel er, at den svenske undersøgelse indikerer, at kvinder i de to lande har en lidt forskellig adfærd i forhold til biblioteker. Begge undersøgelser refererer til en norsk undersøgelse, der også er landsdækkende og meget professionelt gennemført. Det drejer sig om Svanhild Aabø's PhD - afhandling (2004), der anvender kontingent evaluering som metode og dermed får fremstillet, hvilke faktorer der har betydning for borgernes præferencer i forhold til folkebibliotekerne. Denne undersøgelse falder også uden for rammerne, men den peger på, at anvendelse af økonomisk orienterede data kan give meget vigtige informationer om borgernes præferencer.

\section{Resultater}

Gennemgangen af de mange studier vedrørende brugere, hvad enten der er tale om folkebibliotekernes brugere eller uddannelsesbibliotekernes brugere, peger i langt de fleste tilfælde i samme retning; selvom metoderne er forskellige, og undersøgelses-designs ligeledes udviser en meget stor variation, synes resultaterne som helhed at udvise samme tendens. Nedenfor er en sammenfatning af nogle af hovedtendenserne.

I betragtning af de mange ressourcer, der har været anvendt til brugerundersøgelser i de nordiske lande, er der kun i meget begrænset udstrækning anvendt ressourcer til at etablere solide og gennemprøvede forskningsdesign, når vi ser bort fra de undersøgelser, der baserer sig på servicekvalitetsmodellerne, hvor det især er forholdet mellem forventninger og oplevelser, der undersøges. Samme interesse for gennemprøvede måleinstrumenter kan ikke genfindes i forhold til undersøgelser af brugernes faktiske adfærd og præferencer. Det skyldes tvivlsomt, at brugerundersøgelser traditionelt har været opfattet som et lokalt fænomen og som en aktivitet, der primært skal anvendes til tilrettelæggelse af det lokale serviceniveau.

Dette forhold betyder ligeledes, at der kun i begrænset udstrækning satses på at etablere viden, der lader sig generalisere på et metodisk solidt grundlag. Det viser sig ved, at flere af undersøgelserne har et begrænset ambitionsniveau vedrørende repræsentation og i stor udstrækning baserer sig på stikprøver med et vist præg af tilfældighedsudtræk, men dog uden den meget vigtige diskussion af forskelle mellem respondenter og ikke-respondenter. Langt fra alle undersøgelser har foretaget systematiske test af forskningsinstrumenter og respondenternes evne til at besvare spørgeskemaer og lignende.

Det anvendelsesorienterede sigte i mange af anvendelserne viser sig ligeledes i forhold til en ofte begrebsmæssig uklarhed i nogle af undersøgelserne. Der er peget på, at det i flere af undersøgelserne er vanskeligt at skelne mellem for eksempel brugere og brug.

Denne gennemgang viser dog også, at undersøgelser af brugere, deres adfærd, præferencer og aktiviteter i det hele taget med fordel kan undersøges gennem anvendelse af forskellige metoder på samme måde, som en kombination af nationale og lokale undersøgelser er interessant i forhold til opbygningen af systematisk viden om brugerne. Som et eksempel vedrørende fordele ved metodetriangulering kan anføres, at en spørgeskemaundersøgelse kan afdække omfanget af anvendelse af Google i forhold til andre informationsressourcer, men det er interviews og observationer, der kan afdække, hvor i søgeprocessen og til hvad Google anvendes.

Selv med disse metodiske betragtninger in mente er det dog åbenbart, at der i undersøgelserne kan genfindes en række tendenser, der er fælles for brugerne og deres forhold til bibliotekerne.

Det er ligeledes meget tydeligt, at det er næsten meningsløst at tale om brugere som en helhed. De forskellige undersøgelser af uddannelsessøgende viste klart, at der er tale om meget forskellige typer af brugere og mange forskellige adfærdsmønstre og præferencestrukturer. Dette er en meget vigtig viden at have både generelt og $\mathrm{i}$ forhold til de lokale forhold, der skal tages i betragtning, når service skal udvikles og tilrettelægges.

Der er forskelle i studerendes informationsadfærd afhængig af den faglige disciplin, køn, anciennitet eller studietrin samt den måde, som man forholder sig til forsknings- eller studiesituationen på, herunder vurderingen af, hvor vigtig en given opgave er. Dette skal ses i sammenhæng med klare tendenser til, at elektroniske tidsskrifter bliver stadig vigtigere, og at generelle søgemaskiner af mange studerende tydeligvis foretrækkes til lokalisering af materiale og i øvrigt som en vigtig del af søgeprocessen. En forholdsvis let adgang til materialer er også cen- 
tral. De elektroniske ressourcer er uhyre centrale. Det forhindrer ikke, at studerende ikke anvender det fysiske bibliotek. Det gør de i stor udstrækning og undersøgelserne peger på, at det er studerende i de første trin af et uddannelsesforløb, der anvender det fysiske bibliotek mest intensivt. Helt generelt ønsker studerende mere indhold, gerne digitalt, og undersøgelserne peger også på, at opfattelsen af bibliotekerne er traditionel forstået således, at biblioteket især associeres med fysiske dokumenter. Det er også generelt, at omfanget af brug af både biblioteker og informationsressourcer afhænger meget af de krav, der stilles af de studerendes lærere og i studieordningerne i øvrigt. Endelig er de studerendes viden om bibliotekerne som helhed og personalets kompetencer faktisk meget begrænset. Mange af brugerne anvender biblioteket som supplement og især studerende anvender det tilsyneladende som en filial af deres uddannelsesbibliotek.

Dette er nogle af de generelle resultater. De kan ikke betegnes som specielt nye eller epokegørende. Der er dog også resultater, der ikke er helt så entydige. Det er for eksempel meget uklart, om studerende er interesserede $\mathrm{i}$ at medvirke $\mathrm{i}$ bibliotekers anvendelse af sociale medier på samme måde, som der synes at være modstridende opfattelser i litteraturen om forskellige typer af anbefalelsessystemer vil være en styrke i forhold til forskere og studerende. Det er rimeligt at antage, at e-bøger vil få meget større konsekvenser for uddannelsesbibliotekerne end en eventuel satsning på sociale medier.

Studerende og resultater vedrørende disse er medtaget i denne artikel, fordi studerendes generelle adfærd ikke adskiller sig radikalt fra andre borgeres, hvilket deres præferencer heller ikke synes at gøre. Endvidere udgør de studerende en ganske stor del af folkebibliotekernes brugergruppe.

Der kan også ud fra denne oversigt trækkes nogle generelle resultater frem vedrørende brugerne af folkebibliotekerne. Folkebibliotekernes brugere har forholdsvis klare og entydige præferencer vedrørende serviceydelserne. Præferencerne retter sig primært mod faglitteratur og skønlitteratur, som også er de materialetyper, man ønsker mere af. Dette forhold gælder også de brugere, der primært kommer på bibliotekerne for at låne eller anvende andre materialetyper som film og musik. Undersøgelserne viser også, at mandlige og kvindelige brugere har forskel- lige adfærdsmønstre i forhold til anvendelsen af folkebibliotekerne. Alderen spiller også ind, men måske knap så markant som man kunne tro.

En meget stor del af brugerne har mange formål med det enkelte biblioteksbesøg, hvilket er af afgørende betydning for den høje tilfredshed med udbyttet af besøget. Tilfredsheden hænger i forhold til det enkelte besøg sammen med graden af succes. Brugernes adfærd er uhyre differentieret, hvorfor det er problematisk at tale om brugergruppen som en enhed. Det betyder meget for en stor del af brugerne, at afstanden til biblioteket ikke er for lang og at lokalerne er attraktive. Brugerne værdsætter en venlig og høflig betjening og ifølge deres udsagn betyder biblioteksrummets atmosfære også en del. Det betyder dog ikke, at brugerne opholder sig lang tid i bibliotekerne. Brugerne opholder sig generelt kort tid i bibliotekerne bortset fra de grupper, der anvender IT-faciliteter eller anvender især aviser og blade.

Bibliotek.dk og bibliotekernes hjemmesider og den deri mulige selvbetjening bliver stadig vigtigere for flere og flere brugergrupper; det viser sig ved den betydning bibliotekernes hjemmesider tillægges, men også i det forhold, at rigtig mange brugere kommer for at afhente bestilte materialer eller kommer efter bestemte titler, hvilket indikerer at det fysiske biblioteksbesøg er digitalt forberedt.

Brugerne tager nye ydelser til sig. Det viser sig i forhold til fx musik og film, men selvom benyttelsen er stigende betyder det ikke, at præferencerne for mere af disse ydelser bliver væsentlig større. Det udtrykker måske snarere det forhold, at brugerne benytter de tilbud, der er til rådighed, eller sagt på en anden måde: at udbuddet til en vis grad skaber sin egen efterspørgsel. Der er ikke meget, der tyder på at sociale medier og social kollaboration, herunder brugerskabte data vil slå igennem de første par år.

Det måske mest markante resultat for alle typer af brugere i forhold til bibliotekerne er, at det er den skriftlige viden i form af bøger eller artikler - hvad enten de er i papirform eller digital form - der betragtes som det vigtigste. Udlånet af de fysiske bøger afhænger meget af bestandens størrelse og af omfanget af anskaffelser. Bibliotekernes materialevalg har således afgørende indflydelse på brugernes adfærd. 


\section{Konklusion}

De gennemgåede studier udmærker sig for de flestes vedkommende ved, at de har en vis metodisk ambition, der går ud over den rene registrering. Selvom studierne som helhed er meget forskellige i metoder, stikprøver og tilsvarende, er det markant, at der kan uddrages nogenlunde samme tendenser. Det gælder også på tværs af landegrænser. Det er vigtigt at understrege, at selvom tendenserne på det overordnede niveau ser forholdsvis ensartede ud, dækker de over meget forskellige adfærdsmønstre og en meget stor variabilitet mellem forskellige brugersegmenter.

Disse forhold hænger sammen med de forskellige undersøgelsesdesign. Nationale eller ligefrem internationale undersøgelser vil i selve resultatpræsentationen ofte tendere til at udligne de ofte store forskelle, der kan findes i det underliggende materiale. Det forhold ser vi også ved nogle af de danske undersøgelser, hvor der kan være forskelle af betydelig art i enkelte brugerundersøgelser. Disse forskelle er dog sjældent så store, at de direkte bryder de overordnede tendenser.

De analyserede studier er vanskelige at placere i et evidenshierarki. Det skyldes flere forskellige forhold. Det vigtigste er nok, at ingen af undersøgelserne bortset fra Løylands og Ringstads studier har haft til formål at undersøge determinanter og effekter. Deres studier er ligeledes kun indirekte brugerstudier, men er dog dem, der kommer nærmest på at etablere resultater, der befinder sig højt i et evidenshierarki.

Det gælder for både uddannelsesbiblioteker og folkebiblioteker, at det især er det skriftlige indhold, som brugerne sætter pris på. Det skriftlige indhold er også digitalt indhold, som brugeren i alle bibliotekstyper virkelig tager til sig og har som den største og vigtigste præference. For folkebibliotekernes vedkommende kan man i den sammenhæng stille et spørgsmål om det hensigtsmæssige $i$, at man i materialepleje og indkøbspolitik har foretaget en relativ nedprioritering af disse materialetyper på bekostning af andet indhold som musik og film. Musik og film anvendes dog meget hyppigt, og cirkulationsomfanget af disse materialer overgår bøgernes; men det er stadig markant, at selv brugere, der anvender de såkaldt nye medier stadig prioriterer de traditionelle medier højest. Det kan være et spørgsmål om tid før dette ændrer sig.
Situationen er anderledes på forskningsbibliotekerne, hvor vi primært ser en voldsom vækst i antallet af download af især elektroniske artikler.

Anvendelsen af de digitale tjenester på folkebibliotekerne indikerer, at det tager noget tid før de for alvor bliver anvendt $i$ et betydeligt omfang. Noget af anvendelsen vil have bivirkninger, der ikke har været tilsigtede, og hvor betydningen på længere sigt kan være vanskelig at gennemskue. Det gælder fx forhold vedrørende fornyelser, fjernlån og tilsvarende.

Studierne peger endvidere på meget forskellige bruger- og brugsmønstre. Det kan være vanskeligt at gennemskue disse, idet alle undersøgelserne er foretaget som undersøgelser på et bestemt tidspunkt. Der vil derfor være en tendens til at sammenblande et brugsmønster med et andet brugermønster uden der tages hensyn til, at den enkelte bruger over tid udviser mange forskellige brugsmønstre. Dette forhold kan kun undersøges gennem et såkaldt longitudinalt studie, hvor der følges et repræsentativt udvalg over længere tid. Dette ville formentlig også kunne give et bedre grundlag for segmentering, opstilling af persona eller brugertyper.

Generelt set er der behov for udarbejdelsen af mere avancerede protokoller og måleinstrumenter til afdækning af især adfærd og præferencer. Disse instrumenter findes i forhold til målinger af servicekvalitet og tilfredshed. Det er tydeligt, at det ville være hensigtsmæssigt, at der blev udarbejdet validerede instrumenter til undersøgelser af adfærd og præferencer, hvilket kunne lette etableringen og fortolkningen af en evidensbase vedrørende brugeradfærd.

Det ville endvidere være ønskeligt at der blev foretaget et større systematisk review af de mange - oftest lokale - brugerundersøgelser, der foreligger som enkeltstående undersøgelser. I denne forbindelse bør det også understreges, at der i alle de nordiske lande ligger et meget stort antal brugerundersøgelser på biblioteksskolerne i form af kandidatafhandlinger og tilsvarende. Mange af disse har et meget højt både teoretisk og metodisk niveau. Disse burde inddrages $i$ et større systematisk review. 


\section{Referencer}

Aabø, S (2004): The Value of Public Libraries. A Methodological Discussion and Empirical Study Applying the Contingent Valuation Method. Doctoral dissertation, Department of Media and Communication, University of Oslo, Oslo.

ABM skrift 46, (2007). Hvem er de og hvor går de?: Brukeratferd $i$ norske storbybibliotek. Oslo. ABMskrift 46. www.abm-utvikling.no/publisert/abm.../ abm-skrift-46.html/

Akselbo et al (2006). Det hybride bibliotek set med brugernes øjne. www.deff.dk/showfile. aspx?IdGuid=\%7BAA5BDB91-2529

Bille, T et al. (2004). Danskernes kultur- og fritidsaktiviteter 2004. Kbh. AKF.

Brugernes adfcerd på folkebibliotekerne. KL's trafiktcelling 2004. http://www.re-gionbiblioteket.stockholm.se/upload/L\%C3\%A4nsavd/Dokument/Brugernes_adfaerd_pa_folkebibliotekerne.pdf

Gallup (2009). Undersøgelsen foreligger ikke som et samlet dokument, men den kan sammenstykkes gennem Danmarks Biblioteksforenings hjemmeside, hvor man kan anvende søgefeltet. www.dbf.dk søgefelt udfyldes for eksempel med gallup.

Heath, FM et al. (2004). Libraries act on their Libqual Findings. From data to action. New York. Haworth Information Press.

Hernon, P \& Altman, E (1996). Service Quality in Academic Libraries. Norwood, New Jersey. Ablex Publishing Corporation.

Hernon, P \& Whitman, J (2001). Delivering Satisfaction and Service Quality: A customer-based approach for libraries. Chicago. ALA.

Höglund, L \& Wahlström, E (2009). Användingen och attityderne: En rapport om folkbibliotek baserad på SOM-undersökningen. Stockholm. Svensk Bibliöteksförening.

Höglund, L \& Wahlström, E (2009a). Bibliotekets tjänester idag och i morgen? I: S. Holmberg \& L. Weibull (eds) Svensk Höst: Trettiofyra kapitel om politik, medier och samhälle.SOM-rapport 46. Göteborg Universitetet. 165 - 182.

Kofod, A \& Sørensen, NU (2006). Rapport om Unge og biblioteker. Roskilde bibliotek og Danmarks Biblioteksforening.

Kyrillidou, M (2009). Item sampling in service quality assessment survey to improve response rates and reduce respondent burden: The Libqual + lite randomized control trial. Dissertation: https://www.ideals. illinois.edu/bitstream/handle/2142/14570/Kyrillidou_Martha.pdf?sequence $=3$

Løyland, K \& Ringstad, V (2008). Determinants of Borrowing Demand from Norwegian Local Public Libraries. Journal of the American Society for Information Science and Technology 59 (8), 1295-1303.

Løyland, K \& Ringstad, V (2010). Efterfrågan på boklån från svenska folkbibliotek- Statens Kulturråd. Kulturpolitisk forskning.

Martensen \& Grønholt (2003). Improving Library Users' Perceived Quality, Satisfaction and Loyalty: An Integrated Measurement and Management System. Journal of Academic Librarianship. 29 (3) 140 $-147$.

Møller, MR (2005). Trafikanalyse. Brugerne på Hovedbiblioteket i Århus. Århus Kommunes Biblioteker. http://www.aakb.dk/graphics/portal/bibliotekerne/Trafikanalyse2005.pdf

Nilsson, $\AA$ (2009). Den nationale SOM - undersökningen 2008. i S. Holmberg \& L. Weibull (eds) Svensk Höst: Trettiofyra kapitel om politik, medier och samhälle.SOM-rapport 46. Göteborg Universitetet. $445-476$.

Petticrew, M \& Roberts, H (2006). Systematic Reviews in the Social Sciences: A practical guide. Oxford: Blackwell.

Pors, NO (2007). Gymnasieelever og biblioteker. En undersøgelse af 998 gymnasieelevers brug af biblioteker og informationsressourcer. Kbh. Biblioteksstyrelsen. Rapporter fra Biblioteksstyrelsen 5. 62 sider.

Pors, NO (2005). Studerende, Google og biblioteker: Om studerendes brug af biblioteker og informations- 
ressourcer. Kbh. Biblioteksstyrelsen og Danmarks Biblioteksskole. Rapporter fra Biblioteksstyrelsen 4. 2005.

Pors, NO (2006). The public library and students' information needs New Library World 107 (7/8) 275 -285 .

Pors, NO (2008 a). Traditional Use Patterns?: An analysis of high school students' use of libraries and information resources. New Library World 109 (9/10) 431 - 443.

Pors, NO (2008). Trust and Organisational Effectiveness: Discrepancies between users' service preferences and the library system's construction of their needs. Performance Measurement and Metrics 9 (1) 59-68.
Pors, NO (2010). Citizen Services and Public Libraries: An analysis of a new service in Danish Public Libraries. New Library World 111 (7/8) 263-272.

Pressemeddelelse (2009, 7. juli). Presse meddelelse lokaliseret på Danmarks Biblioteksforenings hjemmeside. http://www.dbf.dk/Default.aspx?ID=5777

Suenson, V. et al (2010). Walking the Library. Aalborg Universitet. www.bibliotekerne.hjoerring.dk/ lib/file.aspx?fileID=2724\&target=blank

Thompson, B, Kyrillidou, M et Cook, C (2009). Equating scores on "lite" and long user survey forms. The Libqual lite randomized control trials. Performance Measurement and Metrics 10 (3) 212 -219. 